Ann. Sci. forest., 1980, 37 (4), 345-348.

\title{
Relationships between Nectria coccinea and white rot fungi
}

\author{
K. J. LANG \\ Lehrsiuhl für Anatomie, Physiologie und Pathologie der Pflanzen \\ der Forstwissenschaftlichen Fakultät der Universität München \\ Amalienstrabe 52, 8000 München 40, R. F. A.
}

\section{Summary}

In beech stands attacked by beech bark disease, white rot fungi cause severe financial losses by destroying the wood. Amongst others Fomes fomentarius is of great importance in this respect. From March until the middle of July the fungus produces spores which can germinate under suitable conditions after a few hours.

Experiments in vitro showed that Nectria coccinea supports the development of Fomes fomentorius. The influence involves spore germination, mycelial growth and wood decomposition.

White rot fungi are to find in all beech stands where beech bark disease is present. Because these fungi are responsible for the very fast decomposition of the wood and from this for great financial losses we directed our attention on them.

In our observation areas in the Spessart near Rothenbuch Fomes fomentarius (L. ex Fr.) Kickx is the most important white rot fungus, followed by Fomitopsis pinicola (Swartz ex Fr.) Karst.. Fungi as Bjerkandera adusta (Willd. ex Fr.) Karst., Trametes gibbosa (Pers. ex Fr.) Fr., Coriolus versicolor (L. ex Fr.) Québ. and some others seem to appear later on broken and lying trunks and do not have the importance of Fomes fomentarius.

Certainly one reason for the fast attack and decomposition of damaged trees is the fact, that the fungus produces spores during a long time of the year. By the aid of a spore trap and by slides which were hanging under the fruit bodies spore production of Fomes fomentarius and Fomitopsis pinicola was registrated during 1978. Fomes produced spores from March to the middle of July that means for a longer time as normally it is described in the literature. Spores of Fomitopsis were found during the same time but until the middle of April in smaller quantities. So it might be that Fomes in this respect has an advantage at least before Fomitopsis pinicola.

The germination of basidiospores of Fomes fomentarius was fested on a medium which contained the «slime » which oozes out of the bark as one of the most obvious symptoms of the disease. The mean values in the following table represent the trend of several experiments. 
p. 100 Germination of F. f. spores after 15-19 hrs. (bark 4 min in cold water)

p. 100 germination des spores de F. f. après 15-19 h (écorce placée $5 \mathrm{~min}$ dans l'eau froide)

\begin{tabular}{|c|c|c|c|}
\hline $\begin{array}{l}\text { Temperature } \ldots \ldots \ldots \ldots \ldots \ldots \ldots \ldots \ldots \ldots \\
\text { Control (water agar) } \ldots \ldots \ldots \ldots \ldots \ldots \ldots \ldots \ldots \ldots \\
\text { Bark I }+ \text { slime } \ldots \ldots \ldots \ldots \ldots \ldots \ldots \ldots \ldots \\
\text { Bark II }+ \text { slime } \ldots \ldots \ldots \ldots \ldots \ldots \ldots \ldots\end{array}$ & $\begin{array}{l}15^{\circ} \mathrm{C} \\
10 \\
28 \\
27\end{array}$ & $\begin{array}{l}20 \circ \mathrm{C} \\
33 \\
61 \\
63\end{array}$ & $\begin{array}{l}22{ }^{\circ} \mathrm{C} \\
30 \\
47 \\
56\end{array}$ \\
\hline $\begin{array}{l}\text { Temperature } \ldots \ldots \ldots \ldots \ldots \ldots \ldots \ldots \ldots \ldots \\
\text { Control (water agar) } \ldots \ldots \ldots \ldots \ldots \ldots \ldots \ldots \ldots \\
\text { Fresh slime } \ldots \ldots \ldots \ldots \ldots \ldots \ldots \ldots \ldots \ldots \\
\text { Bark }+ \text { fresh slime } \ldots \ldots \ldots \ldots \ldots \ldots \ldots \ldots \ldots \\
\text { Bark }+ \text { old slime } \ldots \ldots \ldots \ldots \ldots \ldots \ldots \ldots\end{array}$ & $\begin{array}{l}18^{\circ} \mathrm{C} \\
6 \\
62 \\
64 \\
56\end{array}$ & $\begin{array}{l}21^{\circ} \mathrm{C} \\
20 \\
61 \\
63 \\
51\end{array}$ & $\begin{array}{l}24^{\circ} \mathrm{C} \\
54 \\
55 \\
61 \\
55\end{array}$ \\
\hline
\end{tabular}

It is not very surprising that nutrients in the slime accelerale spore germination, especially at relative low temperatures. At higher temperatures the differences decrease.

Germination on extracts of healthy bark treated in the same way was in general smaller as under the influence of slime or diseased bark.

If we take into consideration that the spores of Fomes at $22{ }^{\circ} \mathrm{C}$ begin to germinate after only $5 \mathrm{hrs}$, it is imaginable, that the fungus on a nutrient rich substrate as bark with slime will have a good starting position for colonising beech trunks.

Further it was investigated if there are relations between Nectria coccinea and Fomes fomentarius, especially if products of the metabolism of Nectria have an influence on spore germination, mycelium growth and wood decomposing capacity of Fomes. For these experiments Nectria coccinea was cultivated in malt solution for different times. The culture filtrate was autoclaved with 2 p. 100 agar and used as substrate for germination and mycelium growth tests.

p. 100 germination of Fomes fomentarius after $15-19 \mathrm{hrs}$

p. 100 germination de F. fomentarius après 15-19 h

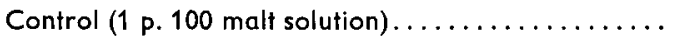

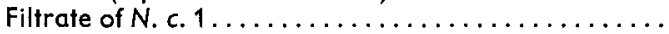

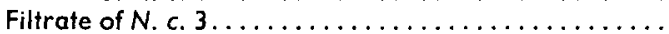

Filtrate of N. c. $4 \ldots \ldots \ldots \ldots \ldots \ldots \ldots \ldots \ldots \ldots$

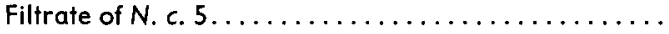

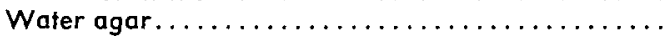

$\begin{array}{lll}68 & 81 & 80 \\ 83 & 86 & 85 \\ 78 & 86 & 87 \\ & 88 & 85 \\ 81 & 85 & 86 \\ & & 40\end{array}$

Germination of Fomes spores was slightly promoted under the influence of Nectria coccinea filtrate but the differences were not significant.

Germination was very good between $\mathrm{pH} 4$ and $\mathrm{pH} 6$ after 24 hrs and after 90 hrs between $\mathrm{pH} 3$ and $\mathrm{pH} 7$ good germination was registrated. At the same time there was poor germination at $\mathrm{pH} 8$ and $\mathrm{pH} 8,5$.

With the same method mycelium growth was tested.

Mycelium growth of white rot fungi influenced by N. c. filtrates 2 weeks old

(p. 100 of the control on 2 p. 100 malt agar)

Croissance mycélienne de champignons lignivores

influencée par des filtrats de cultures de N. c. âgés de 2 semaines

(en p. 100 du témoin sur maltagar 2 p. 100)

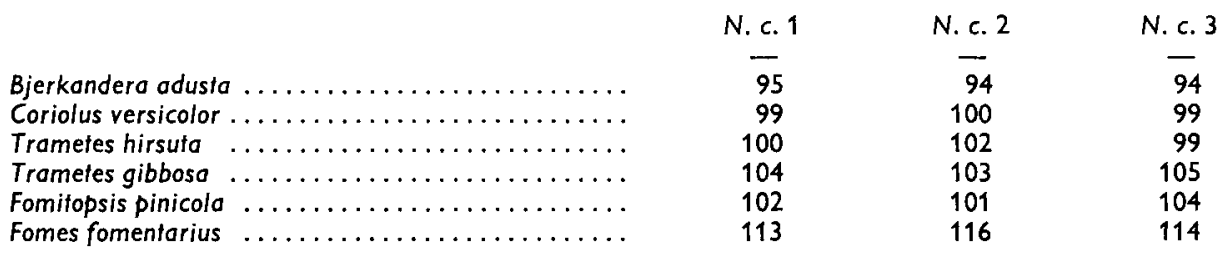


These results are in so far remarcable as the $\mathrm{pH}$ of the control was about 5,5 and the $\mathrm{pH}$ of the filtrate was about 4,0 while the $\mathrm{pH}$ optimum of Fomes lies at about $\mathrm{pH}$ 6. So it could be expected that growth of Fomes would be rather decreased. It seems that perhaps products of the metabolism in the filtrate act stronger than an unfavourable $\mathrm{pH}$.

Although there is no direct local connection between Nectria as a bark inhabiting fungus and Fomes fomentarius as a wood destroying organism, there might exist interrelations at the beginning of wood colonisation. Experiments in vitro showed under certain conditions an increased weight loss of wood under the influence of Nectria coccinea culture filtrate.

Small wood blocks were soaked with malt solution (control) or with a filtrate of Nectria liquid culture and then exposed to the white rot fungus for $2-3$ months.

Weight loss in p. 100 of the control (filtrate 2 weeks old)

p. 100 perte de poids par rapport au témoin (filtrat agé de deux semaines)

Malt solution ( $\mathrm{pH} 5,5)$

2 p. 100 malt

0,2 p. 100 malf

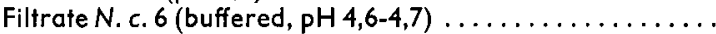

100 (control)

102

100 (control)

Filtrate N. c. 6 (not buffered, pH 3,5-3,7)

117

117

126

It seems that wood decomposing activity depends on the age of the filtrate and on the concentration of the malt solution used.

Filtrate of N. C. 6

Malt solution.......................

Bjerkandera odusta .......

Fomes fomentarius .......

\begin{tabular}{cc}
\multicolumn{3}{c}{ Filtrate of N. c. 6} \\
0,1 p. 100 & 0,5 p. 100 \\
138 & 133 \\
127 & 114
\end{tabular}

\begin{tabular}{|c|c|}
\hline \multicolumn{2}{|c|}{7 days old } \\
\hline $\begin{array}{l}1 \text { p. } 100 \\
70 \\
108\end{array}$ & $\begin{array}{l}2 \text { P. } 100 \\
106 \\
98\end{array}$ \\
\hline
\end{tabular}

N. c. filtrate 2 months old, 2 p. 100 malt solution (not buffered)

Filtrat de N. c. âgé de 2 mois, solution de malt à 2 p. 100 (non tamponné)

Bjerkandera adusta

N. c. 2

Fomes fomentarius

-
102

N. c. 5
$\overline{94}$
107

N. c. 6

87
102

107

- 81

118

This experiment was carried out only once and will be repeated. Some differences to the previous experiments cannot be explained.

Although there are some difficulties in explanation and interpretation of the results it seems that Nectria coccinea is able to do more than kill the bark of predisposed trees. It seems that the fungus has an influence on the development of Fomes fomentarius and perhaps on other white rot fungi. If these influences are important in connection with beech bark disease and if they can help to explain the fast decomposition of the wood are other questions. 


\section{Résumé}

Relations entre Nectria coccinea ef les champignons lignivores

Dans les forêts où sévit la maladie de l'écorce du hêfre les champignons lignivores causent une altération du bois très rapide. En ce qui concerne la destruction des tissus ligneux, Fomes fomentarius est, parmi d'autres champignons, très important. Du mois de mars jusqu'au milieu de juillet. Fomes fomentarius produit des spores qui peuvent germer en quelques heures s'il y a des conditions favorables.

Des expériences in vifro ont montré que Nectria coccinea possède une influence positive sur le développement de Fomes fomentarius. L'influence esł effective sur la germination des spores, la croissance du mycélium ef sur la dégradation du bois.

\section{Zusammenfassung}

\section{Einflüsse von Nectria coccinea auf Weißfäuleerreger}

Im Gefolge der Buchen-Rindennekrose verursachen Weißfäuleerreger erhebliche finanzielle Schäden durch sehr rasche Zersetzung des Holzes. Dabei spielt der Zunderschwamm, Fomes fomentarius, neben anderen eine wichtige Rolle. Fomes fomentarius bildet von März bis Mitfe Juli Sporen, die unter günstigen Bedingungen schon nach wenigen Stunden auskeimen.

Versuche in vifro haben ergeben, daß Nectria coccinea eine fördernde Wirkung auf Fomes fomentarius ausübt. Diese erstreckt sich auf Sporenkeimung, Myzelwachstum und die Intensität des Holzabbaus. 